\title{
Astrologers, soothsayers, scaremongers
}

An Englishman notices a mullah standing outside his house in London scattering grains of maize. He walks over and asks him why he is doing this. 'To keep the tigers away', the mullah replies. The Englishman objects that there aren't any tigers. 'That means it works', says the mullah. ${ }^{1}$

'Overall, the UK response was highly satisfactory. The planning for the pandemic was well developed, the personnel involved were fully prepared, the scientific advice provided was expert, communication was excellent, the NHS and public health services right across the UK and their suppliers responded splendidly and the public response was calm and collaborative."

The statistics of the triumph of public health over swine flu are impressive. After spending an estimated $£ 1.2$ billion, we were left with 30 million unused vaccines (less than a quarter of those eligible took up the jab); 2.7 million phoned the pandemic phoneline (most of these also called our surgeries); 1.2 million people received antiviral medications (although most of them probably did not have swine flu); several people misdiagnosed by the pandemic phoneline died of other conditions. Although both the WHO and the British government warned of viral Armageddon, the final death toll of 457 people was much lower than that resulting from the annual seasonal flu. When Dame Deirdre Hine refers to this as a 'world class' performance, perhaps she means this in the same sense as that of the England football team in South Africa.

Dame Deirdre proclaims 'the near absence of public dissent' and appears to have excluded GPs from her inquiry. This is a pity because we could have shown her our fridges full of unused vaccines, our cupboards overflowing with useless personal protective equipment, our heaps of inscrutable guidelines and pandemic propaganda, and told her of the weeks of disruption to our surgeries and distress to our patients. The concerns of prominent
GPs, such as Michelle Drage and Sam Everington in London, which were widely reported during the pandemic, are simply ignored.

There has been much criticism (ignored by Hine) of prominent public health figures in the UK and in Europe over their links with the manufacturers of vaccines and antiviral drugs who have been major beneficiaries of the swine flu pandemic. No doubt some have a case to answer, especially given concerns over the efficacy of these pharmaceutical products. A more important form of corruption is the readiness of public health authorities to use fear as an instrument of policy. The nearest the Hine Report comes to a criticism of official conduct is the observation that the 'English Chief Medical Officer's citing of the "reasonable worst-case" planning assumption of 65000 fatalities on 16 July 2009 was widely reported in headlines in somewhat alarmist terms'. How else could such an alarmist figure be reported?

Noting that 'ministers and officials set a great deal of store' by the early wildly inaccurate projections of the epidemic based on unreliable and inadequate data on both deaths and the number of affected cases in Mexico, Dame Deirdre asserts that 'modellers are not court astrologers'. ${ }^{2}$ But this, according to Philip Alcabes, is exactly what they are, 'wizards' or 'soothsayers' who have turned public health policy into 'a magic show, the official engaging in legerdemain and the public - the conjurer's audience - agreeing to believe that the official has succeeded in pulling off an inexplicable trick. ${ }^{3}$

\section{REFERENCES}

1. Phillips A. Terrors and experts. Cambridge: MA, 1997.

2. Hine D. The 2009 Influenza Pandemic: An independent review of the UK response to the 2009 influenza pandemic. London: Cabinet Office, 2010 http://www.cabinetoffice.gov.uk/media/416533/th e2009influenzapandemic-review.pdf (accessed 8 Jul 2010).

3. Alcabes P. Dread: how fear and fantasy have fuelled epidemics from the Black Death to avian flu. New York, NY: Public Affairs, 2009.

DOI: 10.3399/bjgp10X515232 